\section{CLOUD-BASED TEMPERATURE MONITORING MECHANISM FOR COVID-19 PANDEMIC TRACKING}

Loo Tung Lun, Tam Swee Chin, Mohamad Khairi Ishak*, Mohd Shahrimie Mohd Asaari

School of Electrical and Electronic Engineering, Universiti Sains Malaysia, Nibong Tebal, 14300, Nibong Tebal, Penang, Malaysia
Article history

Received

10 June 2021

Received in revised form 15 September 2021

Accepted

3 October 2021

Published Online

20 December 2021

*Corresponding author khairiishak@usm.my

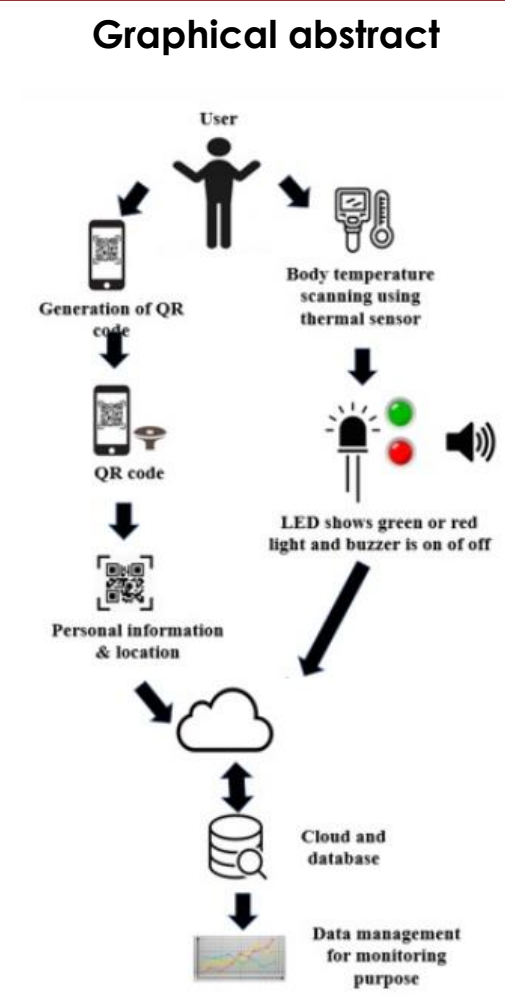

\begin{abstract}
The unprecedented outbreak of novel coronavirus 2019 (COVID-19) globally has a huge impact to our daily life in numerous ways. To effectively minimize the spread of the virus, early symptom detection is crucial, especially in closed environment with high human traffic areas which post higher chances of human-to-human transmission. Body temperature measurement has been identified among the vital monitoring parameters. However, current available temperature monitoring mechanism is costly, limited to single individual and limited to locally without integrating to cloud and database. This led to difficulty in effective surveillance for suspicious COVID cases. Hence, the purpose of this paper is to introduce an end-to-end Internet of Things-enabled application for thermal monitoring as an early signal detection and screening method. This work integrates Raspberry Pi, thermal sensor, LCD display, buzzer, and LED light with Raspbian and Restful API for device-to-cloud communication. The system implemented is capable for user identification, body temperature remote monitoring and warning signal for fever symptoms. The result of this real-time system is capable to detect and screen the suspected contagious person in an organization effectively. Future works on integrating face recognition with machine learning and artificial intelligent enhancement.
\end{abstract}

Keywords: Internet of Things, COVID-19, pandemic, temperature monitoring

\begin{abstract}
Abstrak
Wabak novel coronavirus 2019 yang belum pernah terjadi sebelumnya (COVID-19) di seluruh dunia memberi kesan yang besar kepada kehidupan seharian kita melalui pelbagai cara. Bagi meminimumkan penyebaran virus dengan berkesan, pengesanan gejala awal sangat penting, terutama di persekitaran tertutup dengan kawasan lalu lintas manusia yang tinggi yang mencatat kemungkinan penularan lebih tinggi dalam kalangan manusia. Pengukuran suhu badan telah dikenal pasti antara parameter pemantauan penting. Walau bagaimanupun, mekanisme pemantauan suhu yang ada sekarang terhad kepada tempatan tanpa mengintegrasikan ke awan dan pangkalan data. Ini menyebabkan kesukaran dalam pengawasan yang berkesan untuk kes COVID yang mencurigakan. Oleh itu, tujuan adalah untuk memperkenalkan aplikasi Internet Benda dari hujung ke hujung yang membolehkan pemantauan termal sebagai pengesanan dan penyaringan isyarat awal. Karya ini menyatukan Raspberry Pi, sensor termal, paparan LCD, buzzer, dan lampu LED dengan Raspbian dan Restful API untuk komunikasi peranti ke awan. Sistem yang dilaksanakan mampu mengenal pasti pengguna, pemantauan jarak jauh suhu badan dan isyarat amaran untuk gejala demam. Hasil sistem ini dapat mengesan dan menyaring orang yang disyaki berjangkit dalam organisasi dengan berkesan. Kerja masa depan adalah mengintegrasikan pengecaman wajah dengan pembelajaran mesin dan peningkatan pintar buatan.
\end{abstract}

Kata kunci: Internet Benda, COVID-19, pandemik, pemantauan suhu

(c) 2022 Penerbit UTM Press. All rights reserved 


\subsection{INTRODUCTION}

The unprecedented outbreak of novel coronavirus 2019 (COVID-19) first started from Wuhan City, in the Hubei province of China in December 2019. World Health Organization (WHO) declared COVID-19, which have been causing severe acute respiratory syndrome, as a global pandemic on 11 March. WHO, global confirmed cases is $87,589,206$ and death toll has reached 1,906,606 cases as of 10 January 2021. The fatality rate is around $3.4 \%$ in countries where most of the people receive recovery treatment for free. There is no effective medicine and vaccine is available to contain the disease, and the only prevention method is maintaining social distancing. The rapid rise of number of COVID-19 cases globally has underlined the need of identifying those individuals infected by this virus to control the pandemic. This disease has multiple symptoms for identification where fever is one of the most common symptoms of COVID-19 [1].

Since the incubation time for this disease is long, which is up to 14 days, there has been a need for body temperature monitoring daily at all places to mitigate risk of transmission. Other than body temperature, travel history and dwelling location are other crucial tracking parameters used for contact tracing. Meanwhile, the roles and contributions of Internet of Things (IOT) to fight against this pandemic COVID-19 has been widely discussed, leading to the emergence of IOT enabled technologies and applications being used in screening, contact tracing, and surveillance [2]. In addition, loT-based framework incorporates with real-time symptom information and confirmed COVID-19 cases provides a fast and efficient way to identify the infection cluster [3]. An loT system uses face recognition, one-time Quick Response (QR) code and body temperature using thermal scanning has been developed for symptoms investigation [4]. Furthermore, a study to identify and control the spread of disease within closed environment at workplaces is body temperature evaluation at various checkpoints using medicalgrade infrared sensors, control of proper hygienic standards, coupled with personalized and indoor location data [5].

Lacked information regarding end-to-end temperature monitoring mechanism for closed environment with high human traffics as current available mechanism operate locally without integrating to cloud and database. Even there is endto-end monitoring for thermal monitoring but is costly and limited to single individual. In this paper, an effective end-to-end temperature monitoring mechanism is developed, it is remote, automated with QR code identification, Infrared thermal body temperature monitoring, warning signal and data management for high human traffic area. The paper is organized as follows: Section 2 describes the related works on the Internet of Things for temperature monitoring. Section 3 describes the proposed system integrates hardware, software, and data management. The system implementation and results discussion are reported in Section 4. Finally, Section 5 summarized the conclusion of this work and recommendations for better performances in future.

\subsection{RELATED WORKS}

Internet of Things (IOT) plays a vital role in combating the massive outbreak of COVID-19 where the roles and contributions of IOT have been discussed. Early signal detection of contagious people with fever symptoms is one of the main goals for all countries. Hence, IOT in association with thermal sensors for COVID-19 fever screening and monitoring is widely discussed $[2,6,15,21,22,23]$.

Smart thermometer is used to connect the user body temperature reading to smartphone application through internet. The temperature reading by smart thermometer is fast and accurate, the record of illness is incorporated together in the application [6]. One of the famous smart thermometers is Kinsa Smart Thermometer, which is effective in detecting the cluster though millions of smart thermometers distributed to households in United State of America [7].

Wearable technologies are smart electronic devices that are able to monitor body temperature, heart rate, blood pressure and others when they are attached to our bodies. They are connected through Bluetooth, Cellular Data or Wifi to collect relevant information. The wearable sensors with applications such as temperature sensors, pulse oximeters and impedance sensors in detecting symptoms of COVID19 have been reviewed [8]. A headset, like wearable device consist of sensors, microcontroller, mobile devices and peripheries are used to monitor body temperature, heart rate and respiration rate is developed to track COVID-19 symptoms. This loTenabled application integrates the networking, digital signal processing, data measuring and system to symptoms related to COVID-19 [9].

Telemedicine is one of the applications of IOT in medical industry that does not require physical contact between the patient and the practitioner, and it is practised by doctor to monitor and consult patients for remotely. The wide adoption of telemedicine with focus on COVID-19 [10] and home care systems with telemedicine to remotely treating patients have been studied. A Telemedicine system integrated with health information systems such as wearable devices to detect vital signs are presented in [11]. The platform is integrated with body temperature and location aware network for making patient diagnosis become easy and real-time. The platform layout consists of a sensing node for temperature reading, a local server for data processing, a messaging tool to deliver high fever notification to the doctor and a main server for 
statistical processing of data gathered from all the local servers [12].

Drone has been used as an loT-enabled application for social distancing monitoring purpose. The camera mounted on the drone is able to capture high resolution image and video for remote and realtime monitoring. The images and videos are uploaded through internet to the cloud for data processing and for informing the next action to be taken [13]. Furthermore, drones equipped with infrared sensor, thermometer, thermal cameras and connected to internet are used to measure and screen the body temperature of people who are quarantined in their houses [14].

At work environment, loT-enabled applications have been developed to ensure the health and wellness of workers. A non-contact infrared sensor is used to measure body temperature during their presence to the workplace. Face recognition to mark attendance, QR code scanning to capture the health history as per Arogya Setu app has been deployed. The data recorded uploaded into a database and stored on the cloud [20]. Both noncontact and contact body temperature measurement are discussed in [21], [22], [23], however, to achieve social distancing goal, noncontact thermometers are recommended [23]. Infrared thermometer is effective in detecting body temperature with fever and has strong correlation with outside skin temperature [24]. A smart Infrared thermal scanning with a camera, integrated with Ultraviolet-C spectrum disinfection system, blockchain for data sharing and record management at workplace has been developed [25].

Smart thermometers, wearable technologies, telemedicine systems, and drone thermal systems are applications that are limited to single individual thermal monitoring. It is expensive because every employee in an organisation is required to have the device $[6,7,8,9,10,11,12,13,14]$. Motivated by related works $[20,21,22,23,24,25]$, as well as a lack of information on temperature monitoring mechanisms connecting users to databases. This research gap is worth investigating, as it involves the development of an effective end-to-end temperature monitoring mechanism for effective surveillance in an organisation for high human traffic monitoring purposes.

\subsection{PROPOSED SYSTEM}

Generally, the proposed system consists of 3 frameworks which are hardware, software, and data management [15]. Figure 1 depicts the overall flow of proposed system process.

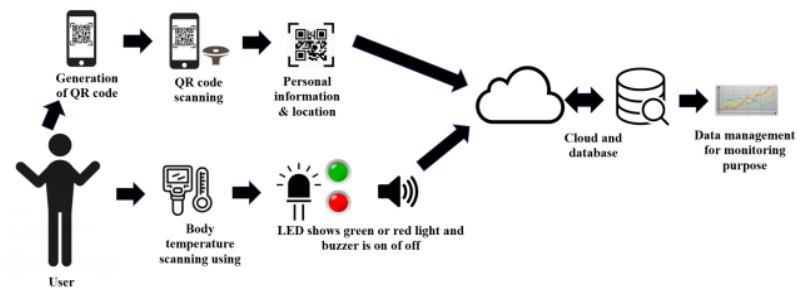

Figure 1 Overall process flows of the proposed system

For identification purposes, the system generates a one-time QR code. By scanning the QR code to the camera module, the personal information associated with the location is captured. The user's body temperature is measured by an infrared thermal sensor. The temperature reading is then displayed on the LCD screen. If the body temperature is less than the threshold value, the LED turns green with the buzzer turned off; if the body temperature is greater than the threshold value, the LED turns red with the buzzer turned on to notify the respective security for decision making. All information, including body temperature, is uploaded to a server and database for data management purposes.

\section{A. Hardware}

Raspberry $\mathrm{Pi}$ is a system on chip (SoC) which consists of ARM central processing unit (CPU) and graphics processing unit (GPU). It has a build in wireless module that can allow the microcontroller to access to WIFI network [25]. Non-contact Infrared thermal sensor is fast, convenient, and safe to use. The forehead infrared thermometer for temperature measurement is widely used to screen people during COVID-19 [26]. The threshold level for fever of $>36.5$ degree Celcius for forehead temperature. In this system, hardware components are listed as Table 1 and Figure 2 shows the actual hardware snapshot.

Table 1 Component lists with description

\begin{tabular}{|l|l|}
\hline Hardware Details & \multicolumn{1}{|c|}{ Description and Purpose } \\
\hline Raspberry Pi 400 & $\begin{array}{l}\text { Single board computer, 1.8 GHz quad- } \\
\text { core ARM Cortex-A72 CPU, 4GB RAM. } \\
\text { Purpose: Core system to process all the } \\
\text { tasks and implement the flow }\end{array}$ \\
\hline $\begin{array}{l}\text { Thermal Sensor } \\
\text { MLX90614 [17] }\end{array}$ & $\begin{array}{l}\text { Infrared thermometer for non-contact } \\
\text { temperature measurements, temperature } \\
\text { range: -40 to } 125^{\circ} \mathrm{C} \text { for sensor temperature. } \\
\text { Purpose: To measure body temperature }\end{array}$ \\
\hline $\begin{array}{l}\text { Logitech C270 } \\
\text { USB Camera [18] }\end{array}$ & $\begin{array}{l}\text { Still resolution: 720p/30fps, fixed focus, } \\
\text { standard lens technology with 60-degree } \\
\text { FoV. Purpose: To scan the QR code and } \\
\text { image }\end{array}$ \\
\hline $\begin{array}{l}\text { LCD Display } \\
\text { sCreen }\end{array}$ & $\begin{array}{l}\text { I2C based 4 rows LCD display. Purpose: To } \\
\text { display user information and the } \\
\text { temperature result }\end{array}$ \\
\hline RGB LED & $\begin{array}{l}\text { Red \& green light-emitting diode. Purpose: } \\
\text { To emit light for signal }\end{array}$ \\
\hline BUzzer & $\begin{array}{l}5 \mathrm{~V} \text { active buzzer. Purpose: To produce } \\
\text { audio signal }\end{array}$ \\
\hline
\end{tabular}




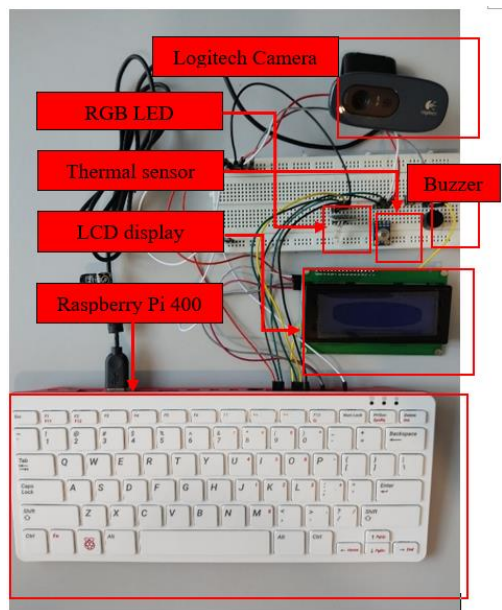

Figure 2 Actual Hardware Snapshot

Hardware block consists of input modules which are camera, thermal sensor, LED, output module LCD display and buzzer connected to Raspberry Pi 400. Then Raspberry Pi 400 is connected two-way to router and server, server consists of PC and Cloud for data management purpose.

\section{B. Software}

As proposed, the system consists of three software categories: operating system, vision library, and language. Figure 3 depicts a software block diagram.

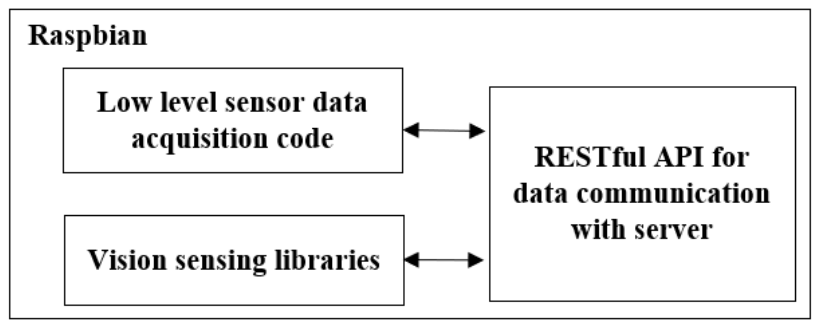

Figure 3 Software block diagram

The QR code implementation is run at Raspbian operating system. QR code generation at user smartphone is using a generic Python library utilizing the qrcode library. The Raspberry Pi camera module captures the QR code for image processing with the OpenCV library, which is based on the Python programming language. There is a QRCodeDetector library in OpenCV that is commonly used to read $Q R$ codes and parse the information. In the case of the LCD module, the message is serialized and sent via the I2C interface. The Thermal Sensor library also uses I2C to collect temperature data. In order for this to work, a system must be capable of supporting two I2Cs. RGB LED modules and buzzers, on the other hand, can be accomplished with only GPIO output.

\section{Data Management}

To perform data extraction for data management, database model implementation is developed. Figure 4 shows the web server block diagram.

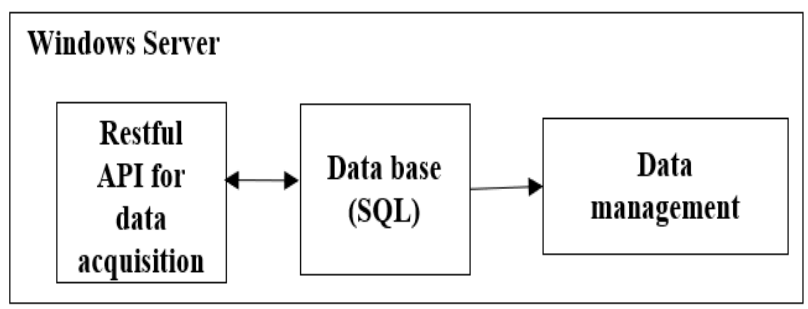

Figure 4 Web server block diagram

This hardware system is linked to the local network, and data is transferred using the device-tocloud communication model. The device collects all usernames, identification numbers, and temperature values before sending them to a server or cloud via RESTful service via HTTP POST. The HTTP POST receiver for this paper is a local server on 127.0.0.1, port 5000. This can also be replaced with any URL link on the Internet and it will still work. Flask and the SQLAlchemy framework are being used to set up this local server. Flask is a Python-based web application framework, and SQLAlchemy provides an API to easily enable database binding [27]. A simple and deployable server database can be created by combining Flask and SQLAlchemy. T. L. Loo has made all of the source code available on GitHub, from component level testing to system level end-to-end integration with a flow chart [28].

Figure 5 depicts a flow chart that explains the proposed system process workflow in an organization.

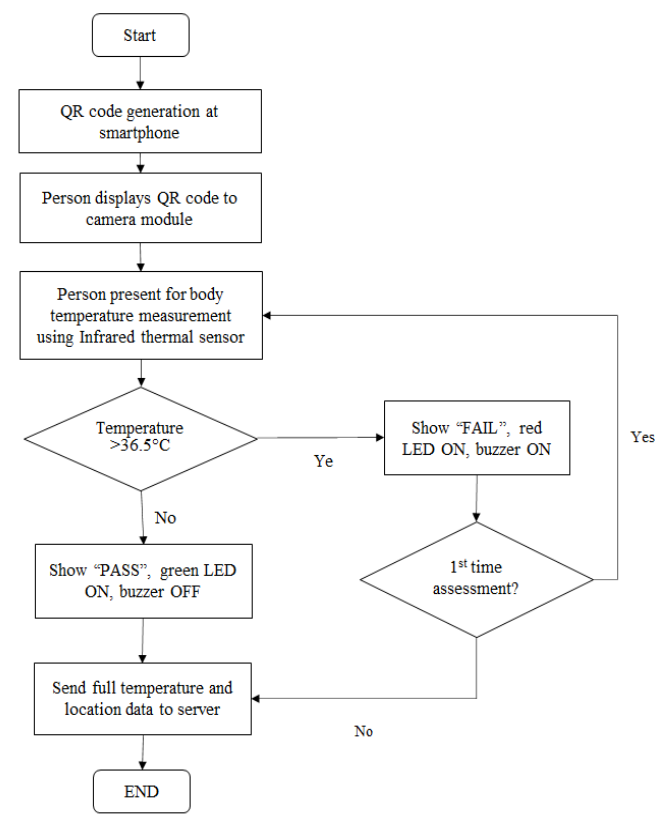

Figure 5 Flow chart of proposed system 


\subsection{SYSTEM IMPLEMENTATION AND RESULTS DISCUSSION}

This section discusses the proposed system's test and evaluation results. The proposed system is fully operational, as illustrated in Figure 6. When the user is in front of the system, the LCD screen displays a message instructing the user to scan the QR code at the camera module. The message "Welcome, please scan the QR code" was displayed on the LCD screen.

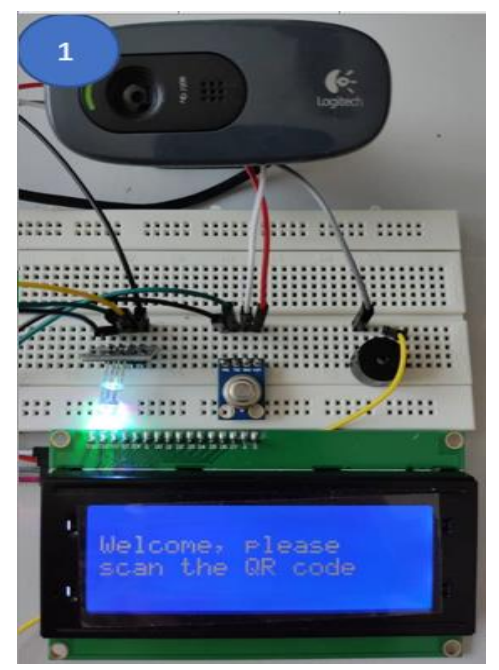

Figure 6 Proposed system setup completed

The QR code is successfully generated at the user's smartphone using the QR code library, as shown in Figure 7. The QR code can easily be scanned by the camera module to capture information for user identification.

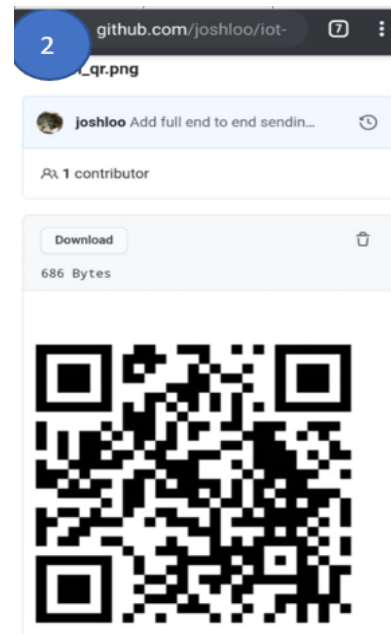

Figure 7 QR code generated

Following the presentation of the QR code, the system prompts the user to place their forehead in front of the Infrared thermal sensor for temperature scanning. Figure 8 shows the message "Wait for valid body temperature." For notification purposes, the LED light was changed to blue.

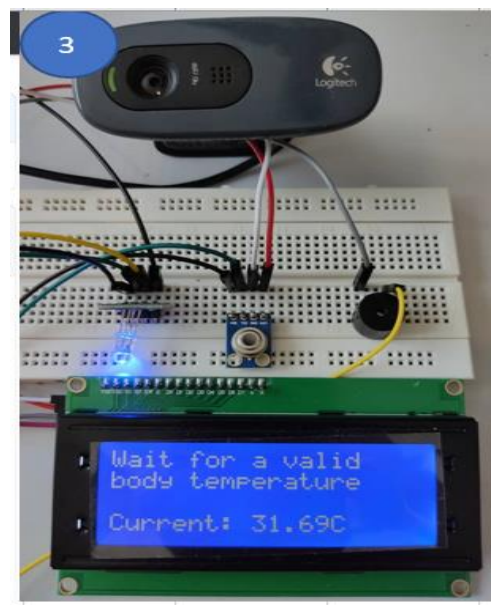

Figure $\mathbf{8}$ Notification to user for thermal scanning

Figure 9 depicts an evaluation of using a thermal sensor to scan the temperature of a user's finger to represent body temperature. When the body's temperature falls below a certain threshold, the system displays a green LED light and the buzzer turns off. This demonstrated that the system is effective and capable of detecting the user's body temperature and responding to signals. For notification purposes, the message "Hi Loo Tung Lun, Body Temperature is 35.83 Celsius" was displayed on the LCD screen.

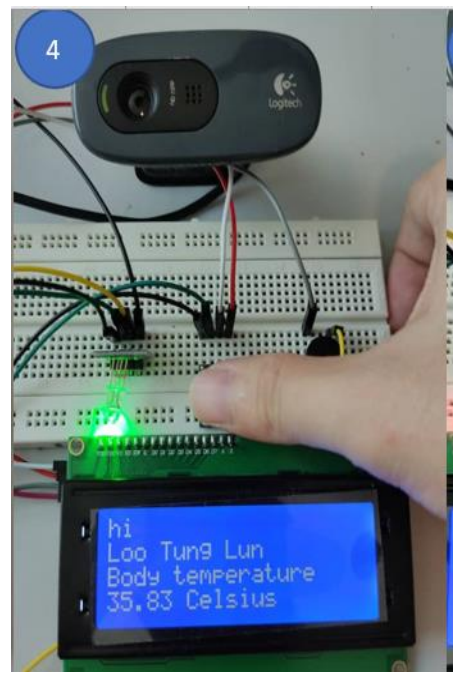

Figure 9 Evaluation of proposed system using finger

As shown in Figure 10, the proposed system is then tested and evaluated again using hot cotton. When the system detects a high temperature, the LED light changes to red and the buzzer activates. "FEVER!!!, Loo Tung Lun, ody Temperature is 51.09 Celcius," the message read. This evaluation revealed that the 
proposed system effectively measures body temperature changes and notifies users via a display screen, LED light, and buzzer.

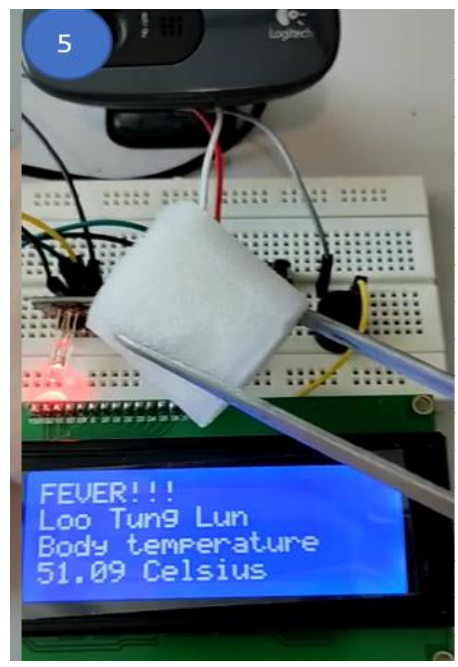

Figure 10 Evaluation using hot cotton

Based on the process flow shown in Figure 5, the user can retry the body temperature scanning process a second time. If the user's body temperature continues to fail, the user is not permitted to enter the building. The finished measurement data is saved in a database. Figure 11 depicted the data management of a fixed location with high human traffic as well as an individual's temperature at various locations using Global Positioning System (GPS) information. This demonstrated that the proposed system is effective in monitoring suspicious COVID cases through data management.

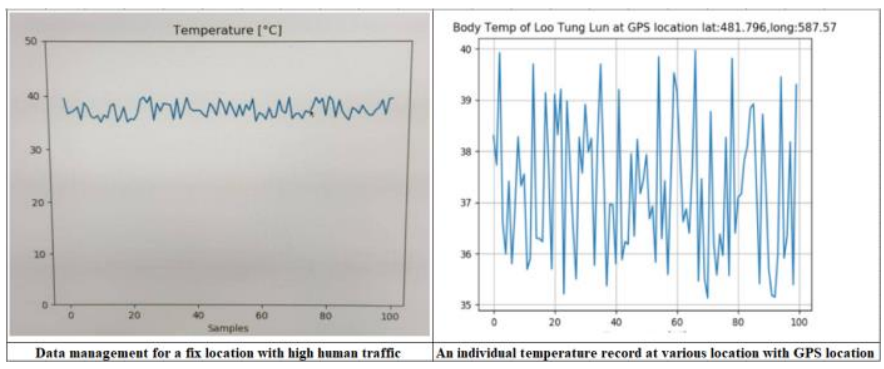

Figure 11 Data management for temperature record and GPS location

The proposed system's thermal sensor reading is validated using a standard infrared thermometer, as shown in Figure 12. The proposed system's reading is comparable to that of a standard thermometer as in Table 2.

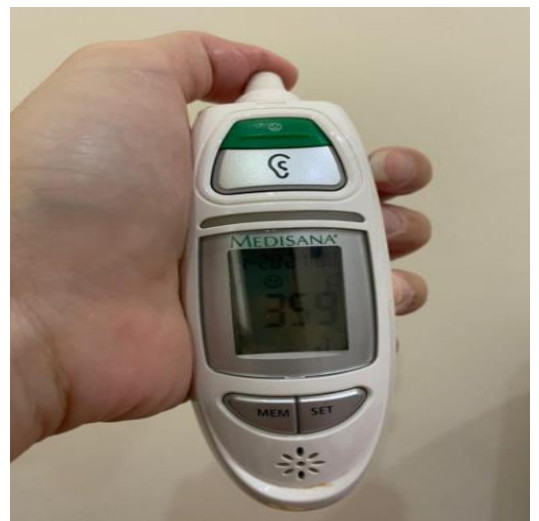

Figure 12 Comparison with normal thermometer using finger

Table 2 Summary of comparison between proposed system and normal thermometer

\begin{tabular}{|c|c|c|}
\hline \multirow{2}{*}{ Reading } & \multicolumn{2}{|c|}{ Temperature (degree Celsius) } \\
\cline { 2 - 3 } & $\begin{array}{c}\text { Normal } \\
\text { thermometer }\end{array}$ & Proposed system \\
\hline 1 & 35.9 & 35.83 \\
\hline 2 & 31.7 & 31.69 \\
\hline 3 & 51.1 & 51.09 \\
\hline
\end{tabular}

In a summary, the results of this temperature monitoring using this proposed system is functioning well and capable to detect the body temperature effectively. This mechanism proven to detect suspected contagious person in an organization. This result closed the research gap where it connected from user for user identification to cloud and database for data management.

\subsection{CONCLUSION}

The goal of creating an end-to-end Internet of Things and cloud based, enabled application for thermal monitoring that integrates hardware, software, and data management for high human traffic areas has been met. An innovative and highly scalable solution that can be configured to support future hardware with minimal integration effort. It is small, inexpensive, and portable, making it suitable for use in any location. If a positive patient is identified, the information from the $Q R$ code and body temperature is critical for future contact tracing. The data is collected on a daily basis and stored in a database, which aids in future work analysis.

\subsection{FUTURE WORK}

Our future works will consider the integration of face recognition to offer better identification and the data management with can be used to perform data analysis using machine learning, Artificial Intelligent and Big Data analysis. 


\section{Acknowledgement}

The work of T. L. Loo, S. C. Tam, M. K. Ishak and M. Shahrimie was supported by School of Electrical and Electronic Engineering, Universiti Sains Malaysia and Intel Sdn. Bhd. Malaysia.

\section{References}

[1] WHO Coronavirus Disease (COVID-19) Dashboard. 2021. World Health Organization. [Online]. Available: https://covid19.who.int/. [Accessed: 17-Jan-2021].

[2] S. Y. Manavi, V. Nekkanti, R. S. Choudhary, and N. Jayapandian. 2020. Review on Emerging Internet of Things Technologies to Fight the COVID-19. 2020 Fifth International Conference on Research in Computational Intelligence and Communication Networks (ICRCICN).

[3] A. Roy, F. Kumbhar, H. Dhillon, N. Saxena, S. Shin and S. Singh. 2020. Efficient Monitoring and Contact Tracing for COVID-19: A Smart IOT-based Framework. IEEE Internet of Things Magazine. 3(3): 17-23.

[4] A. Utsav, A. Abhishek, K. Kant, and R. Kr.badhai. 2020 Unique Identification for Monitoring of COVID-19 Using the Internet of Things (IOT). 2020 5th International Conference on Computing, Communication and Security (ICCCS).

[5] J. Barabas, R. Zalman, and M. Kochlan. 2020. Automated Evaluation of COVID-19 Risk Factors Coupled with Realtime, Indoor, Personal Localization Data for Potential Disease Identification, Prevention and Smart Quarantining. 2020 43rd International Conference on Telecommunications and Signal Processing (TSP).

[6] V. Chamola, V. Hassija, V. Gupta, and M. Guizani. 2020. A Comprehensive Review of the COVID-19 Pandemic and the Role of IOT, Drones, Al, Blockchain, and $5 \mathrm{G}$ in Managing its Impact. IEEE Access. 8: 90225-90265.

[7] Kinsa is an Early Warning System to Detect and Respond to Contagious Illness. Home | Kinsa Health. [Online]. Available: https://www.kinsahealth.co/. [Accessed: 17Jan-2021].

[8] A. Hedayatipour and N. Mcfarlane. 2020. Wearables for the Next Pandemic. IEEE Access. 8: 184457-184474.

[9] R. Stojanovic, A. Skraba, and B. Lutovac. 2020. A Headset Like Wearable Device to Track COVID-19 Symptoms. 2020 9th Mediterranean Conference on Embedded Computing (MECO).

[10] N. Aslani and A. Garavand. 2020. The Role of Telemedicine to Control CoVID-19. Archives of Clinical Infectious Diseases. 15: COVID-19.

[11] J. R. Barr, D. D'auria, and F. Persia. 2020. Telemedicine, Homecare in the Era of COVID-19 \& Beyond. 2020 Third International Conference on Artificial Intelligence for Industries (Al4I).

[12] M. Touil, L. Bahatti, and A. E. Magri. 2020. Telemedicine Application to Reduce the Spread of Covid-19. 2020 IEEE 2nd International Conference on Electronics, Control, Optimization and Computer Science (ICECOCS).

[13] P. K. Singh, S. Nandi, K. Ghafoor, U. Ghosh, and D. B. Rawat. 2021. Preventing COVID-19 Spread using Information and Communication Technology. IEEE Consumer Electronics Magazine. 1-1.
[14] Y. Shen et al. 2021. Robots Under COVID-19 Pandemic: A Comprehensive Survey. IEEE Access. 9: 1590-1615.

[15] M. Ndiaye, S. S. Oyewobi, A. M. Abu-Mahfouz, G. P. Hancke, A. M. Kurien, and K. Djouani. 2020. IoT in the Wake of COVID-19: A Survey on Contributions, Challenges and Evolution. IEEE Access. 8: 186821-186839.

[16] Raspberrypi.org, 2021. [Online]. Available: https://www.raspberrypi.org/products/raspberry-pi-400/. [Accessed: 17- Jan- 2021].

[17] ESP8266. En.wikipedia.org. [Online]. Available: https://en.wikipedia.org/wiki/ESP8266. [Accessed: 17- Jan2021].

[18] Logitech.com. 2021. [Online]. Available: https://www.logitech.com/en-my/product/hd-webcamc270 [Accessed: 17- Jan- 2021].

[19] K. Baskaran, P. Baskaran, V. Rajaram, and N. Kumaratharan. 2020. IOT Based COVID Preventive System for Work Environment. 2020 Fourth International Conference on I-SMAC (IOT in Social, Mobile, Analytics and Cloud) (I-SMAC),

[20] N. S. Yamanoor and S. Yamanoor. 2020. Low-Cost Contact Thermometry for Screening and Monitoring During the COVID-19 Pandemic. 2020 IEEE International IOT, Electronics and Mechatronics Conference (IEMTRONICS).

[21] N. S. Yamanoor, S. Yamanoor, K. Srivastava. 2020. LowCost Design of Non-Contact Thermometry for Diagnosis and Monitoring. IEEE Global Humanitarian.

[22] Center for Devices and Radiological Health. 2021. Noncontact Temperature Assessment Devices During COVID19. U.S. Food and Drug Administration. [Online]. Available: https://www.fda.gov/medical-devices/coronavirus-covid19-and-medical-devices/non-contact-temperatureassessment-devices-during-covid-19-pandemic. [Accessed: 17-Jan-2021].

[23] S. Paramasivam, C. H. Shen, A. Zourmand, A. K. Ibrahim, A. M. Alhassan, and A. F. Eltirifl. 2020. Design and Modeling of IOT IR Thermal Temperature Screening and UV Disinfection Sterilization System for Commercial Application using Blockchain Technology. 2020 IEEE 10th International Conference on System Engineering and Technology (ICSET).

[24] A. Kirimtat, O. Krejcar, A. Selamat, and E. Herrera-Viedma. 2020. FLIR vs SEEK Thermal Cameras in Biomedicine: Comparative Diagnosis through Infrared Thermography. BMC Bioinformatics. 21 (S2).

[25] E. Basil and S. Sawant. 2017. IOT based Traffic Light Control System using Raspberry Pi. 2017 International Conference on Energy, Communication, Data Analytics and Soft Computing (ICECDS).

[26] Hong Kong Medical Device Division. 2018. Proper Use of Thermometers to Measure Body Temperature. Available online:

https://www.mdd.gov.hk/english/emp/emp_gp/files/ther mometer_eng.pdf - Google Search", Google.com, 2021. [Online]. [Accessed: 17- Jan- 2021].

[27] flask-sqlalchemy.palletsprojects.com. 2010, [Online]. Available: sqlalchemy.palletsprojects.com/en/2.x/quickstart/ [Accessed: 20-Jan-2021].

[28] Github.com. 2021. [Online]. Available: https://github.com/joshloo/iot-pandemic-stack. [Accessed: 20- Jan- 2021]. 